\title{
Detection of Virulence inv $A$ Gene in the Salmonella Isolated from Fecal Samples of Poultry by Pcr Method
}

\author{
Mrunalini M. Pawade ${ }^{*}$, Ashok V. Bhosale ${ }^{2}$, Prashant P. Mhase ${ }^{1}$, Mahesh B Kulkarni ${ }^{2}$, \\ SHRIDHAR D BUDHE ${ }^{2}$
}

\section{${ }^{1 *}$ Department of Microbiology, KNP, College of Veterinary Science, Shirwal; ${ }^{2}$ Department of Microbiology, College of Veterinary Science, Udgir; India.}

\begin{abstract}
The presence of Salmonella spp in collected faecal samples was assessed by performing the pre-enrichment and enrichment culture, followed by PCR assay. The primer was selected from the inv $A$ gene, specific for the detection of Salmonella spp. It was observed that 28\% (10/35) of Salmonella were isolated by the conventional method. All Salmonella isolates thus obtained were subjected to PCR for the inv $A$ gene and all were found positive. In order to provide a more accurate profile of the prevalence of Salmonella spp in faecal samples, it was pertinent to use inv $A$ gene specific PCR method that could be considered as rapid technique for identification of Salmonella spp.
\end{abstract}

Keywords $\mid$ Salmonella, InvA gene, Polymerase chain reaction (PCR), Faecal and Simmon citrate agar.

Editor | Kuldeep Dhama, Indian Veterinary Research Institute, Uttar Pradesh, India.

Received | July 05, 2017; Accepted | August 18, 2017; Published | November 23, 2017

*Correspondence | Mrunalini M Pawade, Department of Microbiology, KNP, College of Veterinary Science, Shirwal, India; Email: mrunalinibudhe@yahoo. co.in

Citation | Pawade MM, Bhosale AV, Mhase PP, Kulkarni MB, Budhe SD (2017). Detection of virulence invA gene in the salmonella isolated from fecal samples of poultry by pcr method. Adv. Anim. Vet. Sci. 5(12): 520-522.

DOI | http://dx.doi.org/10.17582/journal.aavs/2017/5.12.520.522

ISSN (Online) | 2307-8316; ISSN (Print) | 2309-3331

Copyright (C) 2017 Pawade et al. This is an open access article distributed under the Creative Commons Attribution License, which permits unrestricted use, distribution, and reproduction in any medium, provided the original work is properly cited.

\section{INTRODUCTION}

S almonella has been implicated as an important foodborne pathogen and thus has been the focus of many epidemiological studies in food animal populations. The majority of epidemiological studies of Salmonella still rely on conventional bacteriological culture methods to detect Salmonella in fecal samples (Davies et al., 2000; Funk et al., 2000). Culture-based methods for Salmonella are laborious and time-consuming, taking up to 7 days to complete, and are inefficient for epidemiological studies in populations with low prevalence of Salmonella, particularly because of the large number of samples that are typically required (Rostagno et al., 2005; Ward et al., 2005).Thus, a rapid, sensitive, and inexpensive method for the detection of Salmonella in fecal samples would enhance the efficiency of epidemiological studies of Salmonella. For accurate profiling of the prevalence of Salmonella spp, the use of inv $A$ gene specific PCR method is considered as an appropriate method. The polymerase chain reaction (PCR) offers a simple and reliable tool for the rapid detection of
Salmonella spp.

Hence, in the present study, PCR was performed for specific detection of Salmonella spp. targeting the inv $A$ gene.

\section{MATERIAL AND METHODS}

Isolation and IdenTification of SALMONELla SpP In the present study, faecal samples of poultry $(n=35)$ were collected and were processed for isolation of Salmonella spp by culturing into selenite $\mathrm{F}$ broth and incubated at $37^{\circ} \mathrm{C}$ for 18 hours. After incubation, each broths were streaked on surface of Salmonella and Shigella agar plates (SS agar) and on Hecktoen Enteric agar (Andrew et al., 1979). Further these plates were incubated for $24 \mathrm{hrs}$ at $37^{\circ} \mathrm{C}$. Presumptive black colonies like Salmonella were isolated and subjected to further biochemical characterization using Triple sugar iron agar (TSI agar) method and Simmons Citrate agar (Ateba, 2014).

Molecular Detection of the Isolates

DNA Extraction: DNA was extracted from the pure iso- 
lates by the boiling method, and for this approx. $1.5 \mathrm{ml}$ of the cultured broth was centrifuged at $10,000 \mathrm{rpm}$ for 5 minutes. The supernatant was discarded and the pellets were washed twice with sterile water. After this, $200 \mu$ of sterile water was added to the pellets, the pellets were vortexed to homogenize and boiled in a dry bath at $100^{\circ} \mathrm{C}$ for 10 minutes. This was followed by vortexing and centrifugation at $12,000 \mathrm{rpm}$ for 5 minutes. The supernatant containing the DNA was transfer to another tube. The purity of the extracted DNA was estimated using a Nanodrop spectrophotometer (Smith et al., 2015).

Primers set and PCR amplification: PCR Salmonellaspecific primers, S139 and S141 (Rahn et.al., 1992) have respectively the following nucleotide sequence based on the invA gene of Salmonella 5' - GTG AAA TTA TCG CCA CGT TCG GGC AA - 3'and 5' -TCA TCG CAC CGT CAA AGG AAC C $-3^{\prime}$. Reaction with these primers were carried out in a $20 \mu \mathrm{l}$ amplification mixture consisting of $10 \mu 1$ of PCR Master mix (Qiagen), 20 pmol of each primer, $3 \mu \mathrm{l}$ of molecular grade water and $5 \mu \mathrm{l}$ of DNA were used in the reaction.

Amplification was conducted in Master-gradient Thermocycler (Eppendorf). The cycle conditions were as follow: An initial incubation at $94^{\circ} \mathrm{C}$ for $60 \mathrm{sec}$. Followed by 35 cycles of denaturation at $94^{\circ} \mathrm{C}$ for $60 \mathrm{sec}$, annealing at $64^{\circ} \mathrm{C}$ for $30 \mathrm{sec}$ and elongation at $72^{\circ} \mathrm{C}$ for $30 \mathrm{sec}$, followed by 7 min final extension period at $72^{\circ} \mathrm{C}$.

Electrophoresis of PCR products: The amplified DNA products from Salmonella specific-PCR were analyzed with electrophoresis on 1.2\% agarose w/v gels stained with ethidium bromide and visualized by UV illumination. A current of $120 \mathrm{~V}$ was applied to each gel. Eight $\mu \mathrm{l}$ of PCR product mixed with two $\mu 1$ of $6 \mathrm{X}$ loading dye were loaded on to agarose gel. A $100 \mathrm{bp}$ DNA ladder (Himedia makeMBT049-50LN) was used as a marker for PCR products.

\section{RESULTS AND DISCUSSION}

The present study supports the ability of these specific primer sets to confirm the isolates as Salmonella. From the 35 fecal samples, 10 isolates were found Salmonella positive as per conventional methods. On Triple sugar Iron agar, the salmonella showed alkaline reaction of the slant with red coloration of the medium, butt showed the acidic reaction with yellowing of the medium with slight gas production. All the isolates were able to utilize citrate as a sole carbon source and showed the change in colour from green to blue. All the 10 Salmonella positive isolates were screened by PCR for inv $A$ gene, and all of them resulted in $284 \mathrm{bp}$ amplified fragment of inv $A$ gene (Karmi, 2013). Detection of inv $A$ in all the isolates proved that they were
Salmonella species (Kocabiyik, 2006) (Figure 1). The inv $A$ gene contains sequences unique to the genus Salmonella and is considered the international standard for its identification (Malorny et al., 2003).

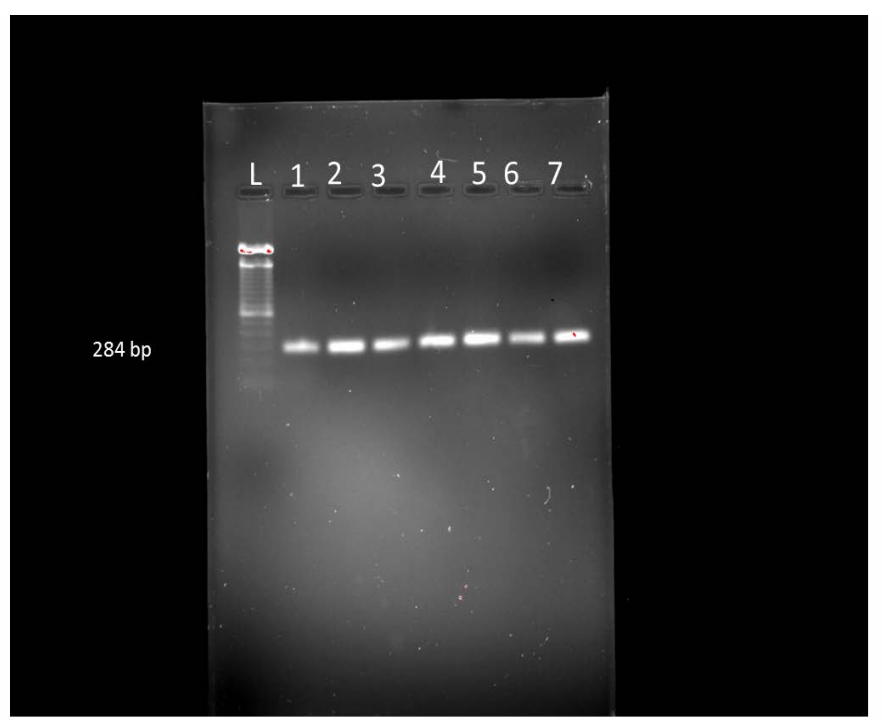

Figure 1: L- Marker Ladder of 100bp, 1- Positive sample, 2, 3, 4, 5, 6 and 7 Salmonella isolates

All Salmonella isolates, positive for the presence of invA gene which is responsible for invasion of cells, have the capacity to invade and survive in macrophages (Gole et al., 2013). The ability of Salmonella specific primers to detect Salmonella species rapidly and accurately is primarily due to the primer sequences that are selected from the gene inv $A$. The inv $A$ gene codes for protein in inner membrane of bacteria, which is necessary for invasion to epithelial cells (Darwin and Miller, 1999). Rapid detection of Salmonella in poultry farms has an effective role in this study. PCR based methods with genus-specific primers belong to inv $A$, according to its quick, specificity and sensitivity is a reliable technique for this proposes. In other hand this technique provides a tool, in confirmation of isolates as Salmonella. Although techniques which in recent years proposed for rapid and reliable detection and confirmation of Salmonella are very progress, but the PCR method which we use in our study, yet is a certain technique in identification and confirmation of Salmonella. The use of this method in most diagnostic and research laboratories is possible and through the molecular basis Salmonella identification techniques, this method is the simplest and a less expensive.

The amplification of the inv $A$ gene has been proposed as an international standard for genus of Salmonella detection (Malorny et al., 2003b). In the present study we used S138 and S141 primers for specific detection of Salmonella and the results of this study highlight the usefulness of the PCR for confirm detection of Salmonella spp from poultry faecal samples. 
In conclusion, with attention to high level of Salmonella infections in poultry farms, it is necessary to consider control programs to prevention of economically loss resulting from mortality and spreading of infection.

\section{ACKNOWLEDGEMENTS}

The author wish to thank the faculty of Department of Microbiology, COVAS, Udgir for providing the facility to carry out the work.

\section{CONFLICT OF INTEREST}

The author declare that there is no conflict of interest.

\section{AUTHORS CONTRIBUTION}

M.M.Pawade: Administration of the whole research work, designing of methodology, standardizing the protocol and drafting of the final version of the article, A.V.BhosaleProvision of the reagents and guidance of the work, P.P.Mhase-Drafting of the article, M.B.Kulkarni- Conducting the research work and S.D.Budhe- Collection of the samples, and drafting the article.

\section{REFERENCES}

-Andrews WH, Wilson CR, Poelma PL, Romero A (1979). J. Ass. Official Analyt. Chem. 62: 320-326.
-Ateba CN, Biotumelo M (2014). J. Food Nutr. Res. 2(6): 294300. https://doi.org/10.12691/jfnr-2-6-5

-Darwin KH, VL Miller (1999). Clin. Microbiol. Rev. 12: 405428. https://doi.org/10.1200/JCO.1999.17.11.3431

- Davies PR, Turkson PK, Funk JA (2000). J. Appl. Microbiol. 89:169-177. https://doi.org/10.1046/j.13652672.2000.01101.x

-Funk JA, Davies PR, Nichols MA (2000). J. Vet. Diagn. Inves. 12:412-418. https://doi.org/10.1177/104063870001200504

- Gole VC, Chousalkar KK, Roberts JR (2013). Int. J. Food Microbiol.164: 161-165. https://doi.org/10.1016/j. ijfoodmicro.2013.04.002

- Kocabiyik AL, Cetin C, Dedicova D (2006). J. Vet. Med. B. 53:194-196. https://doi.org/10.1111/j.14390450.2006.00932.x

- Karmi M (2013). Int. J. Genet. 3(2): 07-12.

- Malorny B, Hoorfar J, Bung C, Helmuth R (2003). Appl. Environ. Microbiol. 69: 290-296. https://doi.org/10.1128/ AEM.69.1.290-296.2003

- Malorny B, Hoorfar J, Hugas M, Heuvelink A, Fach P, Ellerbyoek L, Bunge C, Dorn C, Helmuth R (2003b). Int. J. Food Microbiol. 89: 241-249. https://doi.org/10.1016/ S0168-1605(03)00154-5

-Rahn K, De Grandis SA, Clarke RC, Curtiss R, Gyles CL (1992). Mol. Cell. Probes. 6: 271- 279. https://doi. org/10.1016/0890-8508(92)90002-F

- Rostagno MH, Gailey JK, Hurd HS (2005). J. Vet. Diagn. Invest. 17:80-83. https://doi.org/10.1177/104063870501700118

-Smith SI, Fowora MA, Atiba A, Anejo-Okopi J, Fingesi T,Adamu ME, Omonigbehin EA, Ugo-Ijeh MI, Bamidele M, Odeigah P (2015). Anim. Vet. Sci. 3(1): 22-27. https:// doi.org/10.11648/j.avs.s.2015030101.14

-Ward MP, Alinovi CA, Couetil LL, Wu CC (2005). J. Vet. Diagn. Invest. 17:118-123. https://doi. org/10.1177/104063870501700204 